\title{
Assessment on the management of draft horses in selected areas of Awi Zone, Ethiopia
}

\author{
Bimrew Asmare ${ }^{1 *}$ and Zemenu Yayeh ${ }^{2}$
}

\begin{abstract}
Background: Ethiopia has many equines, which are important for the livelihood of many smallholder farmers in the country. However, there has been no study on the management of draft horses under farmers condition in this area of the country; hence, this study was conducted with the objective to determine the status of horse management and feeding practices in the area. The study areas were selected purposively based on the availability of horses. The study was conducted by administering a semi-structured questionnaire to horse owners and with complimentary information from key informants and secondary data sources.

Results: The majority of household heads were in the age range of 41-50 years in Banja Shekudad district while 51-60 years in Ankesha Guagusa district. Regarding education status, 38 and 34\% of household heads in Banja Shekudad district and Ankesha Guagusa district, respectively, were illiterate. The finding of this study elucidates that horses were used in both districts for many kinds of activities including land cultivation. The purpose of horse keeping in Banja Shekudad districts is ploughing only (32\%) followed by packing of goods (21\%) while packing of goods (31\%) followed by riding only (22\%) in Ankesha Guagusa district. Overall respondents (100\%) noted that horses breed early in rainy season in both districts, which might be associated with availability of feed resources during the rainy season. The majority of horse owners have no training in relation to horses husbandry, while few (24.12\% in Banja Shekudad and 33.78\% in Ankesha Guagusa districts) have got some horse-specific training mainly related to feeding and health care of horses. Horses were kept mainly for ploughing in both districts. Horses were provided supplementary feeds by 49 and $74.5 \%$ in Banja Shekudad and Ankesha Guagusa districts, respectively. Watering of horses was commonly practiced twice a day during dry season while once during wet season. In both districts, the majority of horse owners had no formal training on horse husbandry. Lack of knowledge on horse management and feeding were the major problems observed.
\end{abstract}

Conclusion: In the study area, draft horses are very important in the livelihood of smallholder farmers. However, the overall husbandry of draft horses and feeds and feeding in particular of horses was found to be poor. The reason for such poor husbandry was mainly due to shortage of resources and lack of awareness about management practices. Hence, it is concluded that adequate credit service, training and finding alternative feeds and feeding practices should be addressed to utilize full potential of working horses.

Keywords: Feeds, Grazing, Horse, Husbandry, Supplementation, Working equines

\section{Background}

Equines are extensively spread throughout the world for sports competition, recreation, draft power and food. In

\footnotetext{
*Correspondence: limasm2009@gmail.com

${ }^{1}$ Department of Animal Production and Technology, College

of Agriculture and Environmental Sciences, Bahir Dar University, P.O.

Box 79, Bahir Dar, Ethiopia

Full list of author information is available at the end of the article
}

developed countries, many are kept as pets, as companions, or for work such as land ploughing and packing, in occupational therapy programme [1]. There are about 90 million equines in the developing world, with highest population found in Central Asia and North and East Africa [2]. Of the total equine population, over $95 \%$ of donkeys and mules and $60 \%$ of horses are found in developing countries [3], where they are kept mainly for work. According to [4], there are about 2.03 million horses, 
7.3 million donkeys, 0.3 million mules and 1.16 million camels found in Ethiopia. Mengistu [5] and Ameni [6] noted that in Ethiopia, the rugged terrain characteristics, absence of well-developed modern transport networks and the prevailing low economic status of the community necessitate the use of equines for transportation.

Horses have a prominent position in the agricultural and transport systems of Ethiopia, mainly as draft power, pack and riding animals. In urban and peri-urban set-ups where electromotive power is absent or does not satisfy the transport needs, carts with the aid of horse power are common forms of transportation [7]. Although horses are considered as powerful animals with multiple functions, the management applied in them is at its infant state in Ethiopia. Similarly, the overall management and the status of horses' feeding practice were not described yet in the study area. Thus, this initial survey based was conducted to assess the management of horses, husbandry practice with particular emphasis on feeds and feeding in the study area.

\section{Methods}

\section{Study area}

Banja Shekudad district is one of the districts in Awi administrative zone of Amhara Regional State. The district is situated at latitude of $11^{\circ} 10^{\prime}$ north and longitude of $36^{\circ} 15^{\prime}$ east in a distance of $122 \mathrm{~km}$ away from the regional town Bahir Dar to the south and $447 \mathrm{~km}$ from Addis Ababa to the north with an altitude range of 1900-3300 above sea levels. The annual rainfall of the district ranges from 2200 to $2400 \mathrm{~mm}$ daily temperature of $15-26{ }^{\circ} \mathrm{C}$ the overall area coverage of $47,915.809$ thousand hectares. In terms of land-use pattern, about $65 \%$ of the area is cultivated land and planted settlements and wastelands account for about 10,8 and $17 \%$, respectively [8].

Ankesha Guagusa district is one of the districts in Awi zone, Amhara Regional State. The district is situated at altitude of the coordinates of $10^{\circ} 31^{\prime} 46^{\prime \prime}$ to $10^{\circ} 41^{\prime} 32^{\prime \prime}$ north and $36^{\circ} 36^{\prime} 18^{\prime \prime}$ to $36^{\circ} 59^{\prime} 33^{\prime \prime}$ east and $139 \mathrm{~km}$ away from the regional town (Bahir Dar) and $421 \mathrm{~km}$ from Addis Ababa. The annual rainfall of the area ranges from 1000 to $2000 \mathrm{~mm}$ with the daily temperature of $15-20^{\circ} \mathrm{C}$. The altitude of the district ranges from 1500 to $2800 \mathrm{~m}$ above sea level with total area of 95,503 ha (Fig. 1).

\section{Methods of data collection and analysis Sample selection and study design}

Households possessing at least one horse in the study districts were selected randomly as the study population. A cross-sectional and retrospective type of study was conducted using questionnaire survey, focus group discussion and observation to collect data on characteristics

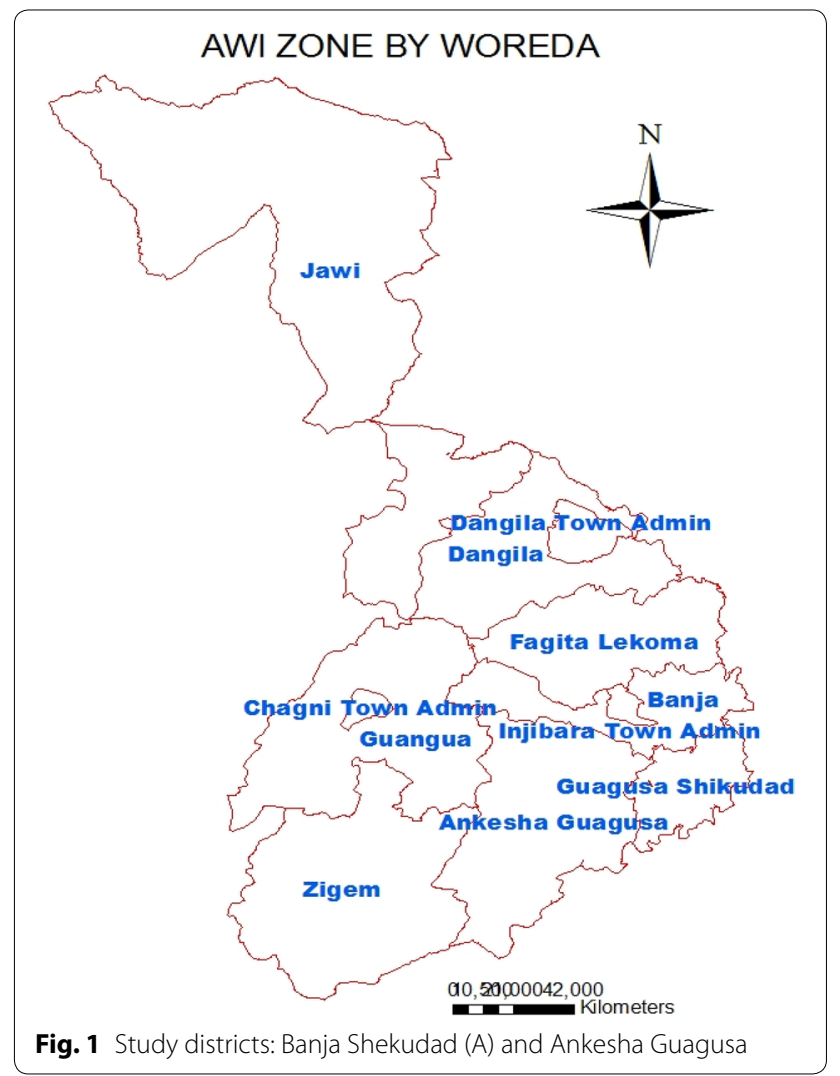

and practices of smallholder horse husbandry systems. The sample size was calculated based on the formula recommended by Poete and Daplyn [9]:

$$
N=(Z C / X)^{2}
$$

where $N$ is the estimated sample size, $Z$ is the confidence level, $C$ is coefficient of variation in the population and $X$ is the accuracy level. With $95 \%$ of confidence level, $50 \%$ coefficient of variation and $5 \%$ of accuracy level, a total of 198 households were required for the study.

Thus, from available population of horse owners in the study area households were selected randomly selected for this study.

\section{Data collection}

The study was conducted from December 2015 to July 2015 in selected districts (Banja and Ankesha Guagusa districts) of north-western Ethiopia. Data were collected using questionnaire interview, group discussion with community who own horses and personal observation. The data collected include landholding and land-use pattern, livestock herd size and composition, purposes of horse husbandry, housing condition of horse, horse feeds and feeding systems, breeding practices, reproductive and productive performance of horse and horse 
production constraints. Data collected through observation of the farm environment were assessing housing conditions, feeding and feed storage practices, and health status of horses and availability of health care services in the area.

\section{Data analysis}

Information collected through questionnaire was extracted and summarized for analysis using SPSS statistical software computer programs (SPSS version 20). Descriptive statistics like percentage and mean were used to describe the farming system management practices of horse production levels and constraints in the study area.

\section{Results}

\section{Household characteristics of respondents}

The household characteristics of respondent household's heads are indicated in Table 1. The majority of respondents in both districts were male headed. Regarding age structure, in Banja Shekudad district the majority $(33.12 \%)$ of respondents were at mid-age $41-50$ years, while in Ankasha most (41.9\%) respondent were at old age.

\section{Educational characteristics of respondents}

The educational status of horse owners in the study (Table 2) noted that the majority (38\% for Banja Shekudad and 34\% for Ankesha Guagusa) of respondents were illiterate. This high illiterate class has got negative impact on livestock production and to accept new technologies regarding management and animal utilization improvement [10]. Therefore, improving education level of farmers has paramount importance in overall agricultural production.

Table 1 Social characteristics of respondents by district $(N=198)$. Source: Survey 2015

\begin{tabular}{lll}
\hline Parameters & $\begin{array}{l}\text { Banja Shekudad } \\
(\mathbf{N = 9 9 )}\end{array}$ & $\begin{array}{l}\text { Ankesha Guagusa } \\
(\mathbf{N = 9 9 )}\end{array}$ \\
\hline $\begin{array}{l}\text { Sex of HHs } \\
\text { Male }\end{array}$ & \\
Female & $87.5 \%$ & $97 \%$ \\
Total & $12.5 \%$ & $3 \%$ \\
Age (years) & $100 \%$ & $100 \%$ \\
$18-30$ & & \\
$31-40$ & $23.11 \%$ & $8.5 \%$ \\
$41-50$ & $17.8 \%$ & $10 \%$ \\
$51-60$ & $33.12 \%$ & $21.5 \%$ \\
$>60$ years & $19.3 \%$ & $41.9 \%$ \\
Average family size $(N)$ & 8.0 & $12 \%$ \\
Total & $100 \%$ & 6.0 \\
\hline
\end{tabular}

Table 2 Educational characteristic respondents by district $(N=198)$. Source: Survey 2015

\begin{tabular}{lcc}
\hline Level of educational & $\begin{array}{l}\text { Banja Shekudad } \\
(\mathbf{N}=\mathbf{9 9})(\%)\end{array}$ & $\begin{array}{l}\text { Ankesha Guagusa } \\
(\mathbf{N = 9 9 )}(\%)\end{array}$ \\
\hline Illiterate & 38 & 34 \\
Read and write & 22 & 19 \\
Grades 1-8 complete & 20 & 16 \\
Grades 9-10 & 12 & 18 \\
Grades 11-12 & 5 & 4 \\
Certificate and above & 3 & 9 \\
Total & 100 & 100 \\
\hline
\end{tabular}

\section{Land and livestock holding}

The characteristics of farming system in both districts were mixed crop-livestock with more or less similar features. The average landholding of respondent in Banja Shekudad districts was 0.84 ha/household, while 1.2 ha/ household was observed in Ankesha Guagusa district. Types of livestock owned by respondents in the two districts were cattle, sheep and goat, mules, horses and donkeys chicken and honey bee colony. The average livestock herd size and composition in the study area are indicated in Table 3. The average livestock holding per house hold in Banja Shekudad and Ankesha Guagusa districts were 7.62 and 8.15 TLUs, respectively. Out of the total TLU of the districts, horses occupy 1.96 and 1.68 TLUs for Banja Shekudad and Ankesha Guagusa districts, respectively. This elucidates that horses are important in the farm household in both districts.

\section{Purpose of horse husbandry in the study districts}

The finding of this study elucidates that horses are used in both districts for many kinds of activities including land cultivation (Table 4). The initial sources of horses in all respondents (100\%) in both districts are purchase from market. The purpose of horse keeping in Banja Shekudad districts is ploughing only (32\%) followed by

Table 3 Average livestock holding (TLU) of respondents by district $(N=198)$. Source: Survey 2015

\begin{tabular}{lll}
\hline Livestock species & $\begin{array}{l}\text { Banja Shekudad } \\
(\boldsymbol{N}=\mathbf{9 9 )}\end{array}$ & $\begin{array}{l}\text { Ankesha Guagusa } \\
(\boldsymbol{N}=\mathbf{9 9 )}\end{array}$ \\
\hline Cows & 1.04 & 1.77 \\
Oxen & 1.23 & 1.1 \\
Sheep + goat & 1.4 & 1.4 \\
Horses & 1.9 & 1.68 \\
Mules & 1.3 & 1.2 \\
Donkeys & 0.75 & 1 \\
Total & 7.62 & 8.15 \\
\hline
\end{tabular}

TLU tropical livestock unit 
packing of goods $(21 \%)$ while packing of goods (31\%) followed by riding only (22\%) in Ankesha Guagusa district.

\section{Feeds and feeding of horses}

Livestock feeding was both partial grazing and home feeding in both districts (Table 5). In Ankesha Guagusa district, $44.4 \%$ of respondents use half-a-day grazing and home feeding using cut fodder and crop residues, while $55.6 \%$ of respondents follow whole-day grazing and nighttime supplementation of their grazing stock. In Banja Shekudad district, $63.4 \%$ of respondents follow half-a-day grazing followed by stall feeding of cut fodder and crop restudies depending on availability with relatively few respondents $36.6 \%$ follow whole-day grazing. The stall

Table 4 Purpose of horses for respondents by district $(N=198)$. Source: Survey 2015

\begin{tabular}{lcl}
\hline Purpose & $\begin{array}{l}\text { Banja Shekudad } \\
(\mathbf{N = 9 9 ) ( \% )}\end{array}$ & $\begin{array}{l}\text { Ankesha Guagusa } \\
(\mathbf{N = 9 9 ) ( \% )}\end{array}$ \\
\hline Ploughing only & 32 & 19.50 \\
Riding only & 17 & 22 \\
Packing of goods & 21 & 31 \\
ploughing and riding & 17 & 10 \\
Packing and riding & 5 & 4 \\
Ploughing and packing & 8 & 13.10 \\
Total & 100 & 100 \\
\hline
\end{tabular}

$N$ number or homestead feeding practiced by some respondents is an interesting feature of livestock feeding with enormous advantage to promote fodder development and to reduce free grazing. This livestock feed practices need to be promoted to overall livestock farmers in the highland areas where grazing areas are decreasing. In both districts, all horse owners provide supplementary diets in both dry and wet seasons for all types of horses (riding, packing and ploughing). The type of supplementary feeds for all horses includes oat and barely grain. Regarding the amount of supplement provided, majority (59\% in Banja Shekudad district and 71\% in Ankesha Guagusa) of respondents supplied higher amount for working horses than non-working horses. The type of supplementary feeds used for grazing animals according to their importance was wheat bran (38.3\%), oat grain and wheat bran (62\%) and other by-products (7.7\%).

\section{Water and watering frequency of horses}

The watering frequency of horses in dry and wet seasons in the study districts is presented in Table 6 . The result noted that the majority of respondents in both districts provide water twice a day in dry season and once in the wet season. The availability and accessibility of water resources have a significant impact on the production and productivity of livestock in general and horses in particular. However, water availability was not reported as problems in the study districts, which might be associated with highland areas in both districts. The sole

Table 5 Feed resources of horses (\% of respondents) in the study districts by season $(N=198)$. Source: Survey 2015

\begin{tabular}{|c|c|c|c|c|c|}
\hline \multicolumn{3}{|l|}{ Dry season } & \multicolumn{3}{|l|}{ Wet season } \\
\hline \multirow[t]{2}{*}{ Type of feed } & \multicolumn{2}{|l|}{ Districts } & \multirow[t]{2}{*}{ Type of feed } & \multicolumn{2}{|l|}{ Districts } \\
\hline & $\begin{array}{l}\text { Banja Shekudad } \\
(N=99)(\%)\end{array}$ & $\begin{array}{l}\text { Ankesha Guagusa } \\
(N=99)(\%)\end{array}$ & & $\begin{array}{l}\text { Banja Shekudad } \\
(N=99)(\%)\end{array}$ & $\begin{array}{l}\text { Ankesha Guagusa } \\
(N=99)(\%)\end{array}$ \\
\hline TS, WB and NSC & 48.31 & 55.11 & Cut forage only & 19.9 & 39.23 \\
\hline TS, WB and BH & 22.79 & 24.9 & Grazing only & 37.5 & 27.27 \\
\hline $\mathrm{BS}$ and $\mathrm{BH}$ & 28.9 & 20 & Grazing and cut forage & 42.6 & 33.5 \\
\hline Total & 100 & 100 & Total & 100 & 100 \\
\hline
\end{tabular}

TS teff straw, WB wheat bran, NSC noug seed cake, BS barley straw, $B H$ bean halum

Table 6 Watering frequency of horses (\% of respondents) in the study districts by season $(N=198)$. Source: Survey 2015

\begin{tabular}{|c|c|c|c|c|}
\hline \multirow[t]{2}{*}{ Frequency of watering } & \multicolumn{2}{|l|}{ Dry season } & \multicolumn{2}{|l|}{ Wet season } \\
\hline & $\begin{array}{l}\text { Banja Shekudad }(N=99) \\
(\%)\end{array}$ & $\begin{array}{l}\text { Ankesha Guagusa }(N=99) \\
(\%)\end{array}$ & $\begin{array}{l}\text { Banja Shekudad }(N=99) \\
(\%)\end{array}$ & $\begin{array}{l}\text { Ankesha Guagusa }(N=99) \\
(\%)\end{array}$ \\
\hline Not provide & 2 & 4 & 18 & 24 \\
\hline Once a day & 25.8 & 35.1 & 70 & 60 \\
\hline Twice & 72.2 & 60.9 & 12 & 16 \\
\hline Total & 100 & 100 & 100 & 100 \\
\hline
\end{tabular}


(100\%) source of water for horse drinking in respondents in the study districts was river water.

\section{Housing, breeding and health care of horses}

In this study, it was observed that all respondents (100\%) in both districts provide shelter at home during night to protect from predators or other factors although the majority of respondents do not have separate houses for horses in both districts (Table 7). Breeding management of horses like other animals has very much economic benefit. However, all respondents in both districts indicated that breeding of horses is random by the horses themselves without any human intervention. Overall respondents (100\%) noted that horses breed early in rainy season in both districts, which might be associated with availability of feed resources during the rainy season.

The major health problems of horses observed were cough and digestion colic. Although some of respondents (35\% in Banja Shekudad district and 31.8\% in Ankesha Guagusa) were used modern veterinary service and drugs to treat their horses against prevailing diseases, it is evident that most of respondents (47\% in Banja Shekudad and 54.2\% in Ankesha Guagusa districts) used homemade treatment for their horses.

\section{Training on horse husbandry}

The majority of horse owners have no training in relation to horses husbandry, while few (24.12\% in Banja Shekudad and $33.78 \%$ in Ankesha Guagusa districts) have got some horse-specific training mainly related to feeding and health care of horses.

\section{Constraints of horse husbandry}

The major constraint noted by all respondents in both districts is shortage of land for horse grazing and feed production. Another is lack of access to credit to buy horse and inputs required for horse management, and incidence of disease is among mentioned problems during group discussion conducted in two sessions with respondents.

Table 7 Housing of horses (\% of respondents) by district $(N=198)$. Source: Survey 2015

\begin{tabular}{lll}
\hline Type of house & $\begin{array}{l}\text { Banja Shekudad } \\
(\boldsymbol{N = 9 9 )}(\mathbf{\%})\end{array}$ & $\begin{array}{l}\text { Ankesha Guagusa } \\
(\boldsymbol{N}=\mathbf{9 9 )}(\%)\end{array}$ \\
\hline No separate house & 45.5 & 40.7 \\
Separate house & 40 & 35.1 \\
Both & 14.5 & 24.2 \\
Total & 100 & 100 \\
\hline
\end{tabular}

\section{Discussion}

\section{Household characteristics}

The sex characteristics of respondents showed that the respondents in both districts were male-headed households that might be due to the fact that males are closely related to livestock handling and management. The maleheaded household characteristics of respondents in both districts were in agreement with Asmare et al. [11] and Wolelie et al. [12] for different parts of Ethiopia. The age structure of household heads in both districts was similar in both sexes. The results of both districts were similar to the reports of Solomon et al. [13]; Asmare et al. [11] who reported the average age of respondents was $43.2 \pm 1.0$ years for Metekel Zone, north-western Ethiopia. The average family size of respondents in both districts in the present study was comparable with Asmare et al. [11] but lower than districts (Mandura and Pawe) of Metekel zone of Benishangul-Gumuz region ranging 6.04-6.94 [14]; the reports by Tesfaye [15] with overall mean family size of 5.7 persons in Metemma district in Northwest Ethiopia and national average (5.20).

\section{Educational characteristics of respondents}

The educational statuses of majority of respondents in both districts were found illiterate, which might be associated with poor education access in the area. The educational characteristics of horse owner respondents were almost to the reports of earlier reports in Ethiopia $[11,12,16]$ for different districts of Ethiopia. This might be due to various factors such as access to education, awareness about the importance of education and other related factors. However, it is important to note that from technology adoption, this higher population of the illiterate class in both districts will have a disadvantage on the acceptance of new technologies like trainings, improved agricultural technologies and adopting them for better live improvement. In other words, adoption of improved technologies should also consider the literacy condition of farmers. Studies by Appleton and Balihuta [17] indicated that education is the main issue in agricultural development. (In particular, primary and secondary schooling had higher impact on agricultural development compared to any other level of education.)

\section{Land and livestock holding characteristics}

Mixed crop-livestock was the characteristic farming system in study districts with more or less similar features. The average landholding of Banja Shekudad districts was 0.84 ha per household, while that of Ankesha Guagusa district was 1.12 ha per household. The landholding per household in both districts was small as compared to the national average of the country. This might be hindrance to respondents in practicing improved fodder production 
for horses and other livestock in the area. The size of landholding per household of both districts is lower than Asmare et al. [11] for Burie-Zuria district in north-western Ethiopia, which was 1.4 ha per household. Moreover, the landholding status of both districts was lower than earlier reports and lower Yayeh et al. [18] in which the landholding of 0.98 ha for Debre Marqos district, Amare [19] with a report of 1.14 ha in Fogera district both are in the same region. Overall, the landholding in both districts is lower than the national average landholding size of 1.6 ha reported by FAO [20], which may in turn affect improved forages.

Horses are the dominant livestock species in Ankesha Guagusa, while cattle are dominant in Banja districts. This observation concurs with the report of Gizachew [21] that generally, equines are the most widely distributed animals in higher and medium highland zones. The average horse holding of respondents in both districts is higher than different reports $[22,23]$ for central highlands of Ethiopia.

\section{Purpose of horse husbandry}

The purpose of horses for the households in the study areas elucidates that horses are used for many activities in both districts mainly for ploughing and as pack animals. The result noted the land cultivation or ploughing using horse power has given much emphasis in the current study area, which is in agreement with earlier reports $[12,22,24,25]$. The result was also in line the studies $[26,27]$ who reported equines can be used for different roles in the farm family daily chores such as transportation of goods by pack and cart due to their sturdy nature and manageable behaviour.

\section{Feed and feeding of horses}

The activity of feeding of horses in both districts was almost similar in that grazing on natural pasture and supplementation using home-grown feeds. This home/ homestead feeding is an interesting feature of livestock feeding, which in turn has enormous advantage to promote fodder development and using cut-andcarry system, thereby reducing free grazing. Regarding the amount of supplement given to horses, the type and amount of feed fed requirement varies according to the workload of the horses. The finding agrees with different results $[25,28,29]$. Similar reports also made by other researchers $[30,31]$. Feed shortage during the dry season and disease were the major constraints for horse production and agree with the reports of other authors for different livestock species. However, in the study area the overall horse feeding and supplementation practice were not quantified, which needs further research in the field.

\section{Water and watering frequency of horses}

The majority of respondents in both districts provide water twice a day in dry season and once in the wet season. The provision of adequate quantities of clean drinking water is a major prerequisite for satisfactory milk production, growth and animal health [32], but the minimum amount required is affected by various factors and therefore seldom known exactly. The availability and accessibility of water resources have a significant impact on the production and productivity of livestock in general and horses in particular. Source of water for horses and frequency of watering is in agreement with Ayza et al. [16]) and Beriso et al. [33] for other species of livestock in different areas of Ethiopia. Letting horses to drink water at least once a day was common feature of all respondents $(100 \%)$ in both districts, which is in agreement with earlier reports [24].

\section{Housing, breeding and health care of horses}

In the study districts, the majority of respondents do not have separate houses for horses in both districts. That means horses were kept within the family house of respondents like the earlier results for horses [21, 26] and other species of livestock [16]. This might be due to lack of awareness and shortage of resources to construct separate horse houses in the study areas. The season of breeding of horses in both districts is early wet season in all respondents (100\%) in both districts. Although breeding management of horses like other animals has very much economic benefit, breeding of horses in all respondents is by the horses themselves without any human intervention. Like other livestock species [34, 35] in most production systems of Ethiopia, no planning of breeding and human-assisted breeding of horses in most cases. According to respondents, horses breed early rainy season in both districts, which might be associated with availability of feed resources associated with the rainy season. The major problems of horses observed are cough and digestion colic in both districts. From overall respondent in both districts, only few get modern veterinary service, while majority use traditional medication for their horses. This might be due to lack of awareness and shortage of capital to afford veterinary services. The finding is in agreement with other equines species such as donkey health management reports in Ethiopia [36, 37 in which few equine species get annually veterinary care and owners also provide home-made treatment ailments to their animals.

\section{Training on horse husbandry}

Even though training access is crucial in improving animal husbandry including horses, majority of horse owners have got no training related specifically to horses, 
while few have some horse-specific training. It is noted that training on livestock husbandry is essential to livestock owners to increase production and productivity of their stock. This finding agrees with earlier reports of Asmare et al. [11] for cultivated forage production and management in selected areas of Ethiopia. It is noted by Ampaire and Rothschild [38] that training on livestock husbandry is essential to livestock owners to increase production and productivity of their stock. Overall, the importance of training of farm households in developing countries (including Ethiopia) also indicates that training has useful effect to improve farm productivity [38-41].

\section{Constraints of horse husbandry}

Feed shortage during the dry season and disease were the major constraints for horse production in both districts. Shortage of feed during dry season might be due to expansion of crop land and decreased feed or fodder production, which can be used for feeding of horses. In Ethiopia, expansion of crop farming in grazing areas was a major problem for horse grazing as reported for other species of livestock [42]. The problem of disease and illness in horses might be linked to lack of awareness on horse healthcare management and improper nutrition of horses. The overall result of this finding agrees with the reports of other authors for different livestock species $[11,13,16]$. The constraints of reported in this study call more research and intervention in horse management in the study districts to exploit the potential of horses in the livelihood of poor farmers in the areas.

\section{Conclusion}

The present finding shows that horses are important animals in the study areas, serving for numerous purposes. Horse management system is found mainly on traditional mixed crop-livestock system in which horses are allowed to graze freely throughout the day in non-working days and off-duty grazing during working days. Although lack of know-how for improved management of horses and feed shortage were the major problems of working horses, supplementation of all working horses with available feed resources was found as a common and useful practice in the study districts. Hence, it is recommended that adequate credit service, training and finding alternative feeds and feeding practices should be sought to use the horses' potential in the socio-economic value for their owners. As this study was an initial assessment on horse husbandry status of the study areas, further comprehensive studies including controlled feeding management should be conducted in future.

\section{Abbreviations}

AGDOA: Ankesha Guagusa District Office of Agriculture; BDOA: Banja District Office of Agriculture; BH: bean halum; BS: barley straw; CSA: Central Statistical Agency; FAO: Food and Agriculture Organization; ha: hectare; km: kilometre; N: number; NSC: noug seed cake; SPSS: Statistical Package for Social Sciences; TS: teff straw; WB: wheat bran.

\section{Authors' contributions}

BA contributed in research proposal writing, data collection, data analysis, data interpretation and article writing. ZY contributed in research data collection, data analysis, data interpretation and article writing. Both authors read and approved the final manuscript.

\section{Authors' information}

Bimrew is an assistant professor of Animal Feeds and Nutrition, currently teaching and conducting research in the area of animal feeds and feeding, animal production and productivity improvement in Ethiopia. Zemenu is a lecturer of Animal Production currently teaching and conducting research in animal production and productivity improvement in Ethiopia.

\section{Author details}

${ }^{1}$ Department of Animal Production and Technology, College of Agriculture and Environmental Sciences, Bahir Dar University, P.O. Box 79, Bahir Dar, Ethiopia. ${ }^{2}$ Department of Animal Sciences, College of Agriculture and Natural Resources, Debre Markos University, P.O. Box 269, Debre Markos, Ethiopia.

\section{Acknowledgements}

The authors would like to acknowledge farmers who participated in interview and group discussion, the office of Agriculture of respective districts for secondary data sources. We are also grateful to Dinberu Workineh and Wasihun Alemenew who helped us during data collection at field level.

\section{Competing interests}

The authors declare that they have no competing interests.

\section{Availability of supporting data}

The datasets used and/or analysed during the current study are available from the corresponding author on request.

\section{Consent for publication}

Not applicable.

Ethical approval and consent to participate

A consent agreement has been confirmed from group discussants used in the current study.

\section{Funding}

Not applicable.

\section{Publisher's Note}

Springer Nature remains neutral with regard to jurisdictional claims in published maps and institutional affiliations.

Received: 5 January 2017 Accepted: 30 November 2017

Published online: 16 December 2017

\section{References}

1. Alujia AS, Lopez F. Donkeys in Mexico. In: Fielding D, Pearson RA, editors. Donkeys, mules and horses in tropical agricultural development. Edinburgh: CTVM; 1991. p. 1-7.

2. FAO Statistical Database Website. Food and Agriculture Organization, Rome, Italy, 2003 (FAOSTATS: http://faostat.fao.org/default.aspx).

3. Fielding D. The number and distribution of equines in the world. In: Proceedings of the colloquium on donkeys, mules and horses in tropical agricultural development, Edinburgh, 3 to 6 September, 1991. p. 62-66. 
4. CSA (Central Statistical Authority). Agricultural sample survey agricultural sample survey livestock and livestock characteristics (private peasant holdings), Ethiopia. 2015. p. 103.

5. Mengistu A. The genetic resources perspective of equines in Ethiopia and their contribution to the rural livelihoods. In: Proceedings of the 11th annual conference of the Ethiopian Society of Animal Production (ESAP), Addis Ababa, Ethiopia, 2003. p. 81-5.

6. Ameni G. Preliminary trial on the reproducibility of epizootic lymphangitis through experimental infection of two horses. Short communication. J Vet. 2006;172:553-5.

7. Bazezew M, Chanie M, Tesfaye T, Kassa A, Mekonnen B, Wagaw N. Lameness and associated risk factors in cart mules in northwestern Ethiopia. Glob Vet. 2014;12:869-77.

8. Banja Shekudad District office of Agriculture (BDOA), 2015. Annual Report (unpublished).

9. Poete CD, Daplyn PF. Data for agrarian development. Cambridge: Cambridge University; 1993.

10. Bekele B. The effect of illiteracy on Rural Development in Jeldu District, Oromia Regional State, Ethiopia. In: A thesis submitted to Indra Gandhi Open University for partial fulfillment of Master Degree of Arts in Rural Development. Addis Ababa, Ethiopia; 2012

11. Asmare B, Demeke S, Tolemariam T, Tegegne F, Wamatu J, Rischkowsky B. Determinants of the utilization of desho grass (Pennisetum pedicellatum) by farmers in Ethiopia. Trop Grassl. 2016:4:112-21.

12. Wolelie B. Smallholder cattle production systems and husbandry management in West Shewa zone of Oromia Regional State, central Ethiopia. World Sci News. 2016;53:178-88.

13. Solomon Z, Binyam K, Bilatu A, Ferede A, Gadisa M. Smallholder cattle production systems in Metekel zone, northwest Ethiopia. Res J Agric Environ Manag. 2014;3:151-7.

14. Mekuriaw Y, Urge M, Animut G. Role of indigenous bamboo species (Yushania alpina and Oxytenanthera abyssinica) as ruminant feed in northwestern Ethiopia. Liverst Res Rural Dev. 2011;23:185.

15. Tesfaye M. Characterization of cattle milk and meat production, processing and marketing system in Metema district, Ethiopia. M.Sc. Thesis, Hawassa University, Ethiopia, 2007.

16. Ayza A, Yilma Z, Nurfeta A. Characterization of milk production systems in and around Boditti, south Ethiopia. Liverst Res Rural Dev. 2013;25:183.

17. Appleton S, Balihuta A. Education and agricultural productivity: evidence from Uganda. J Int Dev. 1996:8:415-44.

18. Yayeh Z, Hailmariam M, Belhu K, Asmare B. Characterization of dairy cattle production systems in Debre Markos District, Amhara Regional State, Ethiopia. Pac J Agric Sci Res. 2014;2:42-51.

19. Amare S. Livestock production systems and available feed resources in different agro-ecologies of north Gondar zone, Ethiopia. An M.Sc. Thesis Presented to the School of Graduate Studies of Haramaya University, $2006.80 \mathrm{p}$.

20. FAO (Food and Agriculture Organization). Country report. FAO, Addis Ababa, Ethiopia, 2008.

21. Gizachew L. Revegetation of degraded range land with Cenchrus ciliaris and Chlories gayanain middle Awash of Afar Region. An M.Sc Thesis presented to the School of Graduate Studies of Alemaya University, 2002. p. 95.

22. Hassen A, Ebro A, Kurtu M, Treydte AC. Livestock feed resources utilization and management as influenced by altitude in the Central Highlands of Ethiopia. Liverst Res Rural Dev. 2010;22:12.

23. Abera M, Tolera A, Assefa G. Feed resource assessment and utilization in Baresa Watershed, Ethiopia. Int J Sci Res. 2014;3:66-72.

24. Mekuria S, Mulachew M, Abebe R. Management practices and welfare problems encountered on working equids in Hawassa town, Southern Ethiopia. J Vet Med Anim Health. 2013;5:243-50.
25. Makki EK, Mohammed Musa EO. Management and field performance of horses and donkeys used for ploughing on smallholder farms. An example from North Kordofan, Sudan. Liverst Res Rural Dev. 2013;25:80.

26. Dinka H, Shelima B, Abalti A, Geleta T, Mume T, Chala R. Socio-economic importance and management of carthorses in the mid rift valley of Ethiopia. In: Pearson RA, Muir CJ, Farrow M, editors. The future for working equines. The fifth international colloquium on working equines. In: Proceeding of an international colloquium held at the Addis Ababa University, Ethiopia, 30th October to 2nd November 2007. The Donkey Sanctuary, Sidmouth, Devon, 2007. p. 181-188.

27. Mekuria S, Abebe R. Observation on major welfare problems of equine in Meskan district, southern Ethiopia. Liverst Res Rural Dev. 2010;22:48.

28. Harris PA. Feeding and management advice for tying up. In: Harris PA, Gomarsall G, Davidson HPB, Green R, editors. Proceedings BEVA specialist meeting on nutrition and behaviour. Newmarket: Equine Veterinary Journal; 1999. p 100-104.

29. Anderson M, Dennis R. Improving animal based transport options, approaches, issues and impact. In: Starkey P, Mwenya E, Stares J, editors. Improving animal traction technology. Proceeding of the first workshop of the animal traction network for Eastern and Southern Africa (ATNESA) held 18-23 January 1992, Lusaka, Zambia; 1994. p. 378-395.

30. Chanie M, Fentahun T, Mitiku T, Berhan M. Strategies for improvement of draft animal power supply for cultivation in Ethiopia: a review. Eur J Biol Sci. 2012;4:96-104.

31. Guyo S, Legesse S, Tonamo A. A review on welfare and management practices of working equines. Glob J Anim Sci Liverst Prod Anim Breed. 2015;3:203-9.

32. Little W, Shaw SR. A note on individuality of drinking water by dairy cows. Anim Prod. 1978;26:225.

33. Beriso K, Tamir B, Feyera T. Characterization of smallholder cattle milk production system in Aleta Chukko District, southern Ethiopia. J Adv Dairy Res. 2015;3:132.

34. Bayou E, Haile A, Gizaw S, Mekasha Y. Characterizing husbandry practices and breeding objectives of Sheko cattle owners for designing conservation and improvement strategies in Ethiopia. Liverst Res Rural Dev. 2014;26:235.

35. Zewdie B, Welday K. Reproductive performance and breeding strategies for genetic improvement of goat in Ethiopia: a review. Greener J Agric Sci. 2015;5:023-33.

36. Mohammed A. Management and breeding aspects of donkeys around Awassa, Ethiopia. In: Fielding D, Pearson RA, editors. Donkeys, mules and horses in tropical agricultural development. Edinburgh: CTVM; 1991. p. 185-8.

37. Niraj K, Fisseha K, Shishay N, Hagos Y. Welfare assessment of working Donkeys in Mekelle City, Ethiopia. Glob Vet. 2014;12:314-9.

38. Ampaire A, Rothschild MF. Effects of training and facilitation of farmers in Uganda on livestock development. Liverst Res Rural Dev. 2010;2010(22):130.

39. Ali M, Flinn JC. Profit efficiency among Basmati rice producers in Pakistan Punjab. Am J Agric Econ. 1989;71:303-10.

40. Wang J, Cramer GL, Wailes EJ. Production efficiency in Chinese agriculture: evidence from Rural Household Survey data. Agric Econ. 1996;15:17-28.

41. Seyoum ET, Battese GE, Fleming EM. Technical efficiency and productivity of maize producers in eastern Ethiopia: a study of farmers within and outside the Sasakawa Global 2000 project. Agric Econ. 1998;19:341-8.

42. Fetsum S, Solomon Z, Mikias D, Yigremachew S, Demeke M, Gizachew W, Yeshi C. Gender based participatory rural appraisal of farming systems in Wombera, Bullen and Guba Woredas. In: Gender differentials for planning agricultural research. Proceedings of the workshop on gender analysis in agricultural research, Addis Ababa, Ethiopia, 2009. p. 161-87. 